\title{
CONCENTRATIONS OF HEAVY METALS IN Eucalyptus AND Pinus WOOD SAWDUST AND SMOKE, COPPERBELT PROVINCE, ZAMBIA
}

\author{
Elisha Ncube ${ }^{1, \wedge}$, Benjamin Phiri ${ }^{1}$
}

\begin{abstract}
The bulk of exotic forest plantations and sawmills in Zambia are within the reach of air pollutants from mines on the Copperbelt province. Up to $60 \%$ of every cubic meter of the timber processed is waste, of which $0,12 \mathrm{~m}^{3}$ is sawdust. Sawdust is largely used for various surface amendments and as a source of energy, but the dangers it poses to users are not known. Heavy metals assimilated by trees or adsorbed by sawdust from the environment may be a health hazard at certain levels. The amount of heavy metals in Eucalyptus and Pinus sawdust was evaluated on samples from Kitwe and Ndola to establish if the use of sawdust for energy and surface amendments was safe. Composite samples for each wood type were collected from each site and digested. The ensuing solution was filtered and analyzed by flame emission Atomic Absorption Spectroscopy for heavy metals. Smoke from a burning test was trapped on Whateman 41 filter paper and the particulate matter that was trapped was extracted. The extract mixture was centrifuged to obtain a clear solution which was then analyzed for heavy metals by AAS. The heavy metal concentrations in Eucalyptus sawdust were 11,5-61,1 $\mathrm{mg} \mathrm{Pb} / \mathrm{kg} ; 3,3-7,9 \mathrm{mg} \mathrm{Cd} / \mathrm{kg} ; 4,9-56,9 \mathrm{mg} \mathrm{Cr} / \mathrm{kg}$ and 20,2-43,4 $\mathrm{mg} \mathrm{Ni} / \mathrm{kg}$ while that in Pinus sawdust were $17,1-32,8 \mathrm{mg} \mathrm{Pb} / \mathrm{kg} ; 5,1-8,6 \mathrm{mg} \mathrm{Cd} / \mathrm{kg} ; 9,9-28,2 \mathrm{mg} \mathrm{Cr} / \mathrm{kg}$ and 18,7-67,4 mg Ni/kg. The concentrations of chromium and cadmium in both wood types from Kitwe exceeded the limit, and so the sawdust was deemed unsuitable for surface applications. This was the same for nickel in Pinus sawdust. The study showed that sawdust from both wood types was not safe for mulching, composting and animal bedding. The annual exposure limits of $0,2 \mu \mathrm{g} \mathrm{Cr} / \mathrm{m}^{3}, 180 \mu \mathrm{g} \mathrm{Ni} / \mathrm{m}^{3}$ and $0,2 \mu \mathrm{g} \mathrm{Cd} / \mathrm{m}^{3}$ set by the World Health Organization were not exceeded by the smoke from both wood types. This suggested that heavy metals embedded on particulate matter from Eucalyptus and Pinus sawdust which has been in storage for about two years in conditions found in Kitwe is unlikely to have adverse short-term health effects associated with heavy metals.
\end{abstract}

Keywords: Eucalyptus cloesiana, Eucalyptus grandis, heavy metals, Pinus kesiya, Pinus oocarpa, wood sawdust stove, wood sawdust smoke.

\section{INTRODUCTION}

The Zambia Forestry and Forest Industries Corporation (ZAFFICO) supplies timber to about 274 smallto-medium size timber processing enterprises, in Kitwe and Kalulushi districts (ZNAS 2014), from its 48,499 ha plantation establishment of Eucalyptus and Pinus (ZAFFICO 2008). Estimates indicate that about 60\%, i.e. $258000 \mathrm{~m}^{3}$, of the $430000 \mathrm{~m}^{3}$ allowable annual cut is converted to waste during harvesting and timber processing (Per. com.; LUMAZ 2013). As a result, the Copperbelt province's landscape is characterized by large piles of sawdust, slabs, offcuts and bark. This indicates that the current wood waste utilization strategies have a limited impact.

Industrialization coupled with population migration into mining centers has increased energy demand to levels that outstrip installed capacity. The Government of the Republic of Zambia (GRZ) and other players are considering alternative energy sources (Energy Regulation Board 2012) such as solar, mini/micro-hydro, biomass, geothermal and wind (Energy Regulation Board 2008). Efficient woodfuel cook stoves programs supported by GRZ, non-government organizations and the private sector encourage sustainable use of fire wood in rural areas and charcoal in urban settlements (Simfukwe 2010).

\footnotetext{
${ }^{1}$ Copperbelt University, School of Natural Resources, Department of Biomaterials Science and Technology, itwe, Zambia.

^ Corresponding Author: elisha.ncube@cbu.ac.zm

Received: 17.03.2014 Accepted: 21.01.2015
} 
Wood smoke is an aerosol, of hazardous gases, wood tars, volatile organic compounds (VOCs), polycyclic aromatic hydrocarbons, heavy metals and soot, which is made visible by the presence of particulate matter (PM) (Chaiyo et al. 2011, Ravindra et al. 2001). The cumulative distribution of PM is $91,8 \%(<1 \mu \mathrm{m}) ; 93,1 \%$ $(<2,5 \mu \mathrm{m})$ and $95,8 \%(<10 \mu \mathrm{m})\left(\right.$ EPA 1984). The hazardous substances embedded on PM especially $\mathrm{PM}_{2.5}$ are carried deeper into alveoli where they cause harm and interfere with gaseous exchange (EPA 1984). The toxicity of smoke from wood heating devices, which can be twice as much that from oil and gas heating units, offsets the obvious attractiveness of wood as a renewable material (Larson and Koenig 1993). However, the composition and toxicants concentrations in wood smoke can be controlled by burning of wood with moisture content below $20 \%$ with adequate ventilation to realize complete combustion and most usable energy as well as smaller concentrations of harmful substances (Minnesota Pollution Control Agency n.d.). Unfortunately, most of the domestic biomass combustion technologies being used in Zambia discharge unknown mixes and quantities of air pollutants and so expose humans and the environment to hazardous materials.

In Zambia, large exotic forest plantations are located in the Copperbelt province where most anthropogenic heavy metals from mining activities and traffic exhaust gases (UNEP/GPA 2004; Ward et al. 1974) are discharged into the environment. The dispersal of heavy metals such as lead $(\mathrm{Pb})$, cadmium $(\mathrm{Cd})$, copper $(\mathrm{Cu})$, and zinc (Zn) in soil from a mine source, especially by rain can extend to over a $20 \mathrm{~km}$ radius within which pollution levels can be much higher than is recommended by the World Health Organization (Liteinturier et al. 2001). Most sawmills generating sawdust in Kitwe lay within the reach of air laden with heavy metals. Wood exposed to heavy metals during growth or in storage is most likely to be contaminated, but there is no mechanism for protecting sawdust users in Copperbelt province. In the USA, certain local authorities have placed a ban on wood stoves and open burning and the Environment Protection Agency has specified emission standards for wood stoves and encourages consumers to switch to cleaner wood burning appliances (Minnesota Pollution Control Agency n.d.).

Heavy metals are natural components of the environment, but there is a concern on their accumulation in soil, water and air at alarming rates and levels. This is attributed to the rapid population growth, increased urbanization and expansion of industrial activities (Aksoy et al. 2000). A heavy metal is defined as any metallic substance with atomic weights between 63,5 and 200,6; and a specific gravity 5 times greater than that of pure water (Duruibe et al. 2007, Dimple 2014). There are 53 heavy metals found in nature (Ambulkar et al. 1994) as constituents of earth's crust in the form of sulphides and oxides (Duruibe 2007). For example, the sulphides of lead and cadmium are naturally found occurring in trace amounts together with sulphides of iron (pyrite, FeS2) and copper (chalcopyrite, CuFeS2) (Duruibe 2007). These trace heavy metals are released as part of exhaust fumes in pyrometallurgical processes.

Heavy metals are persistent environmental contaminants responsible for several human illnesses (Luckey et al. 1975). Small amounts of heavy metals can enter the body system through food, air, and water and bioaccumulate over a period of time (UNEP/GPA2004). Heavy metal contamination is an important environmental issue since they are non-biodegradable (Wu and Zhang 2010). Hence they are not readily detoxified and removed by metabolic activities once they are available in the environment. This may subsequently lead to their build up to toxic levels, through bio-accumulation in ecosystems or human tissues. Bio-accumulation of heavy metals in man, animals and plants result in metal poisoning (Audu and Lawal 2005). The heavy metals documented to commonly cause problems in humans include lead, mercury, cadmium, arsenic, nickel and aluminium as they tend to accumulate and disrupt normal function in the brain, kidneys and immune system (Passwater and Cranton 1993). 
The sawdust stove technology on the Zambian market has the potential for use in tobacco curing, domestic heating and cooking, and in organic manure production. However, there is a concern that the proximity of forest plantations and sawmills to flue gas emissions from mining activities contaminate wood with unacceptable levels of heavy metals. Consequently, the suitability of sawdust from the Copperbelt province for surface applications and as a source of energy must be evaluated. Information on the type and amount of heavy metals present on wood sawdust is required to safe guard the health of current and prospective consumers.

This was a preliminary study to establish whether heavy metals contamination levels in wood waste and wood smoke comply with national and international air pollution thresholds. This will generate data for assessing the suitability of wood sawdust for energy and surface applications. The authors are not aware of similar studies on heavy metals contamination of wood material from the Copperbelt and their concentration in wood smoke.

\section{MATERIALS AND METHODS}

\section{Materials Collection And Preparation}

The major Pinus species in ZAFFICO plantations are Pinus kesiya Royle ex Gordon and P. oocarpa Schiede ex Schlechtendal, while Eucalyptus grandis Hill ex Maid. and E. cloesiana Muell. are the major Eucalyptus (ZFFICO 2008).

Freshly cut sawdust originating from the Ndola plantation block was collected from Rainlands Timber Ltd in Kakolo which is $15 \mathrm{~km}$ outside Kitwe. The fresh sawdust provided a reference for the quantification of heavy metals assimilated and accumulated by wood during the growth of a tree. Wood sawdust which was produced about two years ago was collected from Kitwe Wood and Logs Ltd in a relatively polluted Kitwe urban area on the Copperbelt province. This sawdust helped determine the effect of airborne pollutants' adsorption by sawdust in storage.

Pinus and Eucalyptus sawdust was collected separately at each site. At each point on a site, a $2 \mathrm{~kg}$ subsample was collected up to $10 \mathrm{~cm}$ below the surface on five points randomly distributed over a sawdust pile and the sawdust kept in airtight polythene bags (ASTM E 872-82 2006) until further testing. A composite sample for each site was made by mixing the subsamples. Sawdust sieve analysis gave a mean particle size of $1,4 \mathrm{~mm}$ and 1,1 $\mathrm{mm}$ for Pinus and Eucalyptus, respectively.

The moisture content of each composite sample was determined by oven drying (ASTM D 4442-92 2003).

\section{Analysis of heavy metals in wood sawdust}

One gram of Pinus and Eucalyptus wood sawdust was separately placed in $250 \mathrm{~mL}$ beaker and acid digested with $10 \mathrm{~mL}$ of concentrated nitric acid $\left(\mathrm{HNO}_{3}\right)$. Four replicates were used for each composite sample. The mixtures were boiled for 25-35 minutes to oxidize all the easily oxidizable organic matters. When all the organic matters were acid digested, $4 \mathrm{~mL}$ of $70 \%$ perchloric acid $\left(\mathrm{HClO}_{4}\right)$ was then added following cooling. Heating was repeated until red nitrogen dioxide $\left(\mathrm{NO}_{2}\right)$ fume production ended indicating completion of wood sawdust digestion. After cooling, the solutions were transferred in $50 \mathrm{~mL}$ volumetric flasks and filled with distilled water. The solution was then filtered using a $45 \mu \mathrm{m}$ filter paper.

The concentration for heavy metals; lead, chromium, cadmium and nickel, in the solution were determined by flame emission Atomic Absorption Spectroscopy (AAS). This was calibrated using the analytical (working) curve technique and the standard solutions. 


\section{Analysis for heavy metals in wood sawdust smoke}

A wooden stick of $45,75 \mathrm{~mm}$ diameter by $296 \mathrm{~mm}$ long was placed at the center of $187 \mathrm{~mm}$ diameter by $305 \mathrm{~mm}$ long by $1 \mathrm{~mm}$ thick mildsteel sheet sawdust stove to link with an air inlet pipe of $71 \mathrm{~mm}$ long in order to produce a natural air draft from the base to the top of the stove. Air dry sawdust specimen $\left(0,006 \mathrm{~m}^{3}\right)$ with a characteristic density value of $290 \mathrm{~kg} / \mathrm{m}^{3}$ at $13-19 \%$ moisture content was burnt until the fire temperature reduced to $20^{\circ} \mathrm{C}$ after about $2,5 \mathrm{~h}$. The fire was ignited by a $4,4 \mathrm{~g}$ pine resin wood stick. Three burning tests were done for each wood type from each of the three sampling sites. Temperature was measured at an interval of 3 minutes by a thermocouple placed between the laboratory jar and stove.

The smoke particulates from burning $1,74 \mathrm{~kg}$ of wood sawdust was trapped on Whatman 41 filter paper (pore size $\leq 4 \mu \mathrm{m}$ ) in an assembly of laboratory jar, flat bottom flask and Vacubrand ${ }^{\mathrm{TM}} 80$ bars vacuum pump with a 1,9-2,2 $\mathrm{m}^{3} / \mathrm{h}$ air displacement capacity (Figure 1). Each filter paper was clamped at the top of the laboratory jar connected to a vacuum pump to collect particulate matter (PM) as wood sawdust was burnt. PM was retained by a combined mechanism involving electrostatic attraction, Van der Waals forces, inertia and diffusion at a collection efficiency of $63 \%(\mathrm{PM} 0,32 \mu \mathrm{m})$ for a single trial (EPA 1984). At the cessation of smoking, 89 and 83 minutes for Pinus and Eucalyptus sawdust, the filter paper was removed and then weighed.

Each of the nine blank and PM loaded filter papers was oven dried for 15 minutes at $105^{\circ} \mathrm{C}$ and weighed on an analytical balance with a sensitivity of $\pm 0,0001 \mathrm{~g}$.

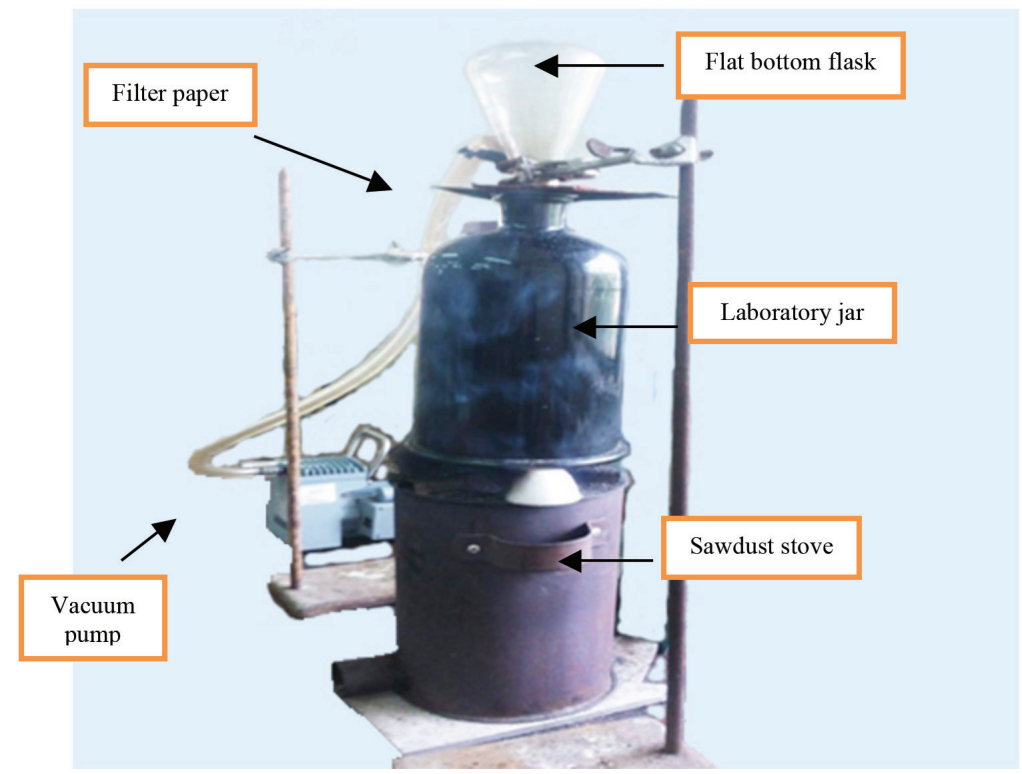

Figure 1. Apparatus for the collection of smoke particulate matters from burning Pinus and Eucalyptus wood sawdust. 
PM trapped on filter paper was extracted in a mixture of $10 \mathrm{~mL} \mathrm{3 \%} \mathrm{HNO}_{3}$ and $8 \% \mathrm{HCl}$ in a glass tube for 2 hours at $130^{\circ} \mathrm{C}$ (Nwajei and Iwegbue 2007). The mixture was centrifuged for 30 minutes at $1500 \mathrm{RPM}$ to obtain a clear solution upon settlement of impurities at the base. The solution was transferred into glass vessels and diluted to $20 \mathrm{~mL}$ mark with distilled water and analyzed for heavy metals by AAS. Heavy metal concentration was calculated by equation 1 (Chaiyo et al. 2011)

$$
C=\frac{\text { Metal } \mathrm{x} \text { Extraction solvent }}{W_{P M}}
$$

where $C$ equals Concentration of metal in $\mathrm{mg} / \mathrm{mg}$ of particulate mater (PM) (mg/mg PM), Metal equals Heavy metal concentration in the analyzed solvent $(\mathrm{mg} / \mathrm{L})$, Extraction solvent equals Volume of solvent used for extraction of heavy metal (L), and WPM equals Weight of PM collected on a filter paper (mg). The concentrations of heavy metals found in equation 1 were converted to $\mu \mathrm{g} \mathrm{M} / \mathrm{m}^{3}$ based on the amount of PM retained on a filter after drawing 2,84 $\mathrm{m}^{3}$ and 3,04 $\mathrm{m}^{3}$ of air in each test run for Eucalyptus and Pinus sawdust, respectively.

\section{Data analysis}

The concentrations of $\mathrm{Pb}, \mathrm{Cd}, \mathrm{Cr}$ and $\mathrm{Ni}$ in wood sawdust and in the particulates retained on paper filter from the ensuing smoke were analyzed using one-way analysis of variance (ANOVA) at 5\% level of significance. Fisher's least significant difference method was employed to identify significant differences (one-way ANOVA $\left.\mathrm{F}_{\text {calc. }}>\mathrm{F}_{\text {tab. }}, \mathrm{P}<0,05\right)$ by multiple pair comparison technique using Minitab ver. 16.

\section{RESULTS AND DISCUSSIONS}

\section{Time-temperature curves}

The moisture content of Eucalyptus and Pinus sawdust from Kitwe was 11,8\% and 18,5\%; which was much similar to material from Ndola, i.e. $13,4 \%$ and $19,0 \%$. Pinus sawdust fire reached a lower maximum temperature $\left(567^{\circ} \mathrm{C}\right)$ than for Eucalyptus sawdust $\left(710^{\circ} \mathrm{C}\right)$ (Figure 2) due to heat loss associated with energy expended on drying the additional $6 \%$ moisture.

Figure 2 shows time-temperature curves for Eucalyptus and Pinus sawdust. The combustion of sawdust was characterized by simultaneous drying over 6 minutes, which was followed by degassing (arrows in Figure 2 ) and carbonization in the last phase. The longer degassing periods for both Eucalyptus (66 minutes) and Pinus (75 minutes) sawdust from Kitwe indicated that exposed sawdust released potentially toxic gases over a longer period compared to fresh sawdust from Ndola. As the fire spread during degassing, wet sawdust was encountered and the effect caused slight temperature depression in wetter sawdust from Ndola. As degassing progressed, wood sawdust degraded into charcoal layers during carbonization and burnt at decreasing rate to $73^{\circ} \mathrm{C}$ over about 2 hours. These conditions are appropriate for cooking an ordinary family meal using the sawdust stove. 


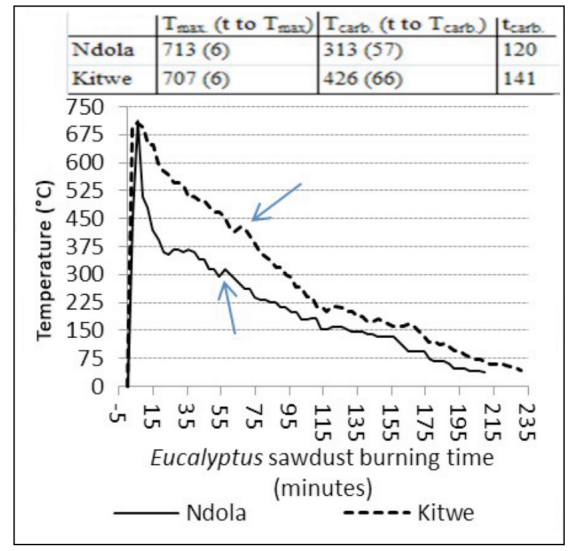

(a)

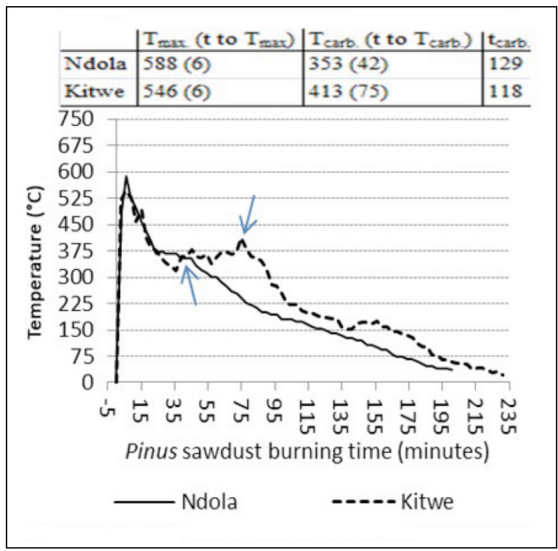

(b)

Figure 2. Time-temperature curves for (a) Eucalyptus and (b) Pinus sawdust.

The arrows show degassing termination point. $\mathrm{T}_{\max }$ stands for maximum temperature $\left({ }^{\circ} \mathrm{C}\right), \mathrm{t}$ to $\mathrm{T}_{\max }$. stands for time (minutes) taken to reach the maximum temperature, $\mathrm{T}_{\text {carb. }}$ stands for temperature at the beginning of carbonization, $\mathrm{t}$ to $\mathrm{T}_{\text {carb. }}$ stands for time it takes to reach carbonization and $\mathrm{T}_{\text {carb. }}$ stands for the duration of carbonization up to $73^{\circ} \mathrm{C}$.

\section{Heavy metals concentrations wood sawdust}

A one-way ANOVA ( $\left.\mathrm{F}_{\text {calc. }} 37,9>\mathrm{F}_{\text {critic. }} 2,1 ; \mathrm{P}<1,8 \times 10^{-16}\right)$ at a $5 \%$ level of significance in conjunction with Fisher's least significance different analysis showed that Eucalyptus sawdust from Kitwe had higher concentrations of $\mathrm{Pb}^{\mathrm{a}}$ and $\mathrm{Cr}^{\mathrm{a}, \mathrm{b}}$ than sawdust from Ndola (Figure 3a). This was not the case with Pinus sawdust where $\mathrm{Ni}^{\mathrm{a}}$ is the only one which showed significantly different concentrations (Figure $3 \mathrm{~b}$ ). The fresh sawdust from Ndola only shows the amount of heavy metals which trees assimilated together with essential trace metals from the soil. It is possible that sawdust which had been in storage for over two years adsorbed additional heavy metals from the polluted air in Kitwe urban. Airborne particulates accumulate on the wood surface, forming a mono- or multi-layer film (Dimple 2014).

The Waste and Regeneration Action Program and the British Standard Institution stipulate contaminant upper limits in waste wood (British Standard Institution 2012) as $90 \mathrm{mg} \mathrm{Pb} / \mathrm{kg}, 25 \mathrm{mg} \mathrm{Cr} / \mathrm{kg} ; 1,5 \mathrm{mg} \mathrm{Cd} / \mathrm{kg}$ and $50 \mathrm{mg} \mathrm{Ni} / \mathrm{kg}$. The sawdust from both sites and species is not safe for particleboard manufacture as it had Cr concentrations which exceeded the upper limit. Similarly, the Eucalyptus and Pinus sawdust from both sites is not safe for surface applications such as, mulching, composting and animal bedding, as the concentrations of $\mathrm{Cd}$ exceeded the maximum value of $1,5 \mathrm{mg} / \mathrm{kg}$. Nwajei and Iwegbue 2007 , detected $40-250 \mathrm{~Pb} \mathrm{mg} / \mathrm{kg}$; $0,05 \mathrm{Cd} \mathrm{mg} / \mathrm{kg}$ and 1,46-160,50 Cr mg/kg in sawdust at Sepele sawmill in Nigeria. Unlike in this study, the concentration of Cd in sawdust from Sepele was the only one safe. The Ni concentration of 67,4 mg/ $\mathrm{kg}$ in Pinus sawdust from Kitwe also indicated that the material is also not suitable for surface applications as it was above the $50 \mathrm{mg} / \mathrm{kg}$ limit. 

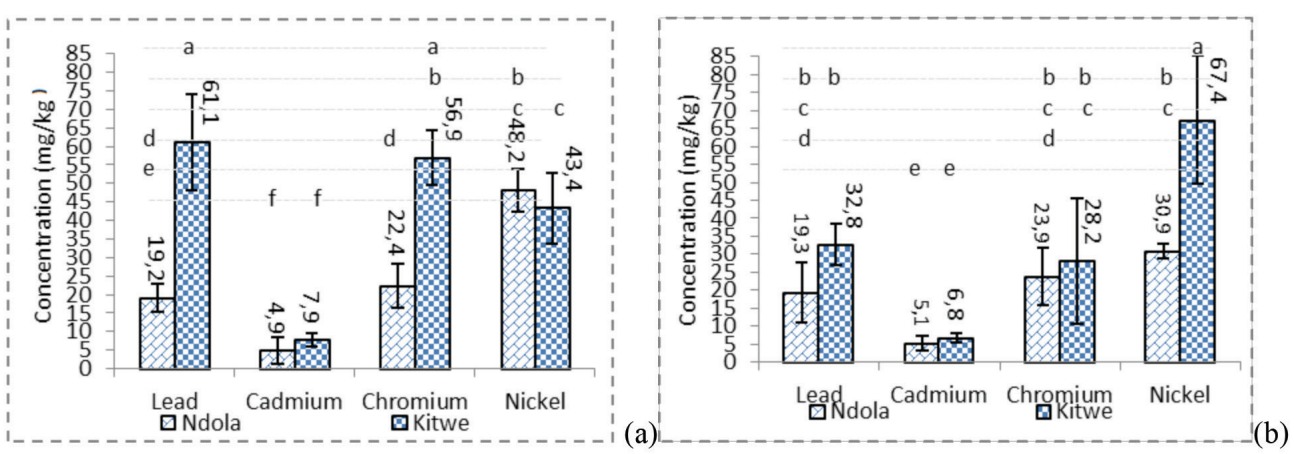

Figure 3. Heavy metal concentrations in Eucalyptus (a) and Pinus (b) wood sawdust from Ndola and Kitwe in Copperbelt province. Values represent means for four replicates per site. Values followed by the same letter(s) are not significantly different from one another. $\alpha=0,05$.

Eucalyptus and Pinus sawdust from Kitwe had been exposed for over two years to air pollutants at a sampling site within a $5 \mathrm{~km}$ radius of the business district and copper mines. The principal anthropogenic sources of trace metals in the atmosphere are smelting of metallic ores, industrial fabrication and commercial applications of metals, as well as burning of fossil fuels. This was different for fresh sawdust from Ndola where the major source of heavy metals was the natural environment. Trace heavy metals have been detected in tree leaves, roots and anatomical features of the stem (Mala et al. 2007, Lawal et al. 2011).

It has been reported that climate variables, atmospheric depositions, the concentrations of heavy metals in soil, the nature of soil on which the trees are grown and the degree of maturity of the plants at time of harvest have a bearing on uptake and bioaccumulation of heavy metals in trees (Lake et al. 1984, Voutsa et al. 1996). The uptake of heavy metals by Pinus sylvestris is a complex process whose efficiency depends on the soil $\mathrm{pH}$, redox potential, soil texture, soil organic matter content, soil metal content and metal availability (Seregin and Ivanov 2001).

The heavy metals in the environment are absorbed by plants via the roots from which they are transported to the leaves or absorbed directly into the leaves by air or precipitation (Kord et al. 2010) and accumulate in small amounts (Cambra et al. 1999). Studies have shown that heavy metal concentrations in wood increment correlate with metal concentrations in the environment and can indicate local environmental contamination (Baltrenaite et al. 2010) levels from anthropogenic, biogenic, or geogenic sources (Daly and Zannetti 2007). Various plants, such as spot pine (Yilmaz and Zengan 2003), have been used as bioindicators to assess the impact of pollution source on mine vicinities (Onder and Dursun 2006). So the heavy metals found in fresh sawdust from Ndola were largely assimilated by trees from biogenic and geogenic sources (Daly and Zannetti 2007). As an area becomes more industrialized, the level of environmental pollution escalates. This effect explained the significantly lower concentrations of heavy metals in freshly sawn sawdust from Ndola compared to that from Kitwe.

\section{Heavy metal concentrations wood sawdust smoke}

The visible smoke in the air from wood-burning stoves and fireplaces is a complex mixture of gases and a collection of particulate matter (PM), i.e. small collections of materials that had not quite burnt or have burned into ash that is light enough to float up the air. PM tends to be bits of wood fiber, burnt wood tar, and other light deposits, usually inhalable $\mathrm{PM}_{10}$ (coarse particulates less than $10 \mu \mathrm{m}$ in diameter) as well as respirable $\mathrm{PM}_{2.5}$ (fine particulates less than 2,5 $\mu \mathrm{m}$ in diameter) (Gingrich and Macfarlane 2002, WHO 2000, EPA 1984). A kilogram of wood burnt in a new wood stove produces about $21 \mathrm{~g}$ of fine particulates (EPA 1984; Larson and Koenig 1993; Abelson 1994). Dry wood sawdust was used because wet sawdust emits more heavy smoke containing a lot more PM (Levine 1990; Butcher and Sorenson 1979). "Dried wood used for fuel typically has a moisture content of 5-20\%" (Ragland and Aerts 1991). 
Figure 4 shows an array of selected heavy metals concentrations in smoke realized when wood sawdust specimens were burnt in laboratory conditions. The heavy metals concentrations in wood were much lower than what was found in wood sawdust smoke. This indicated that the bulk of the metals were retained in the ash fraction (Lupupa 1997) or where attached to ultrafine PM that was not retained by the filter paper. So, the wood ash contained similar levels of heavy metals and so could restrict the use of ash as a surface amendment.

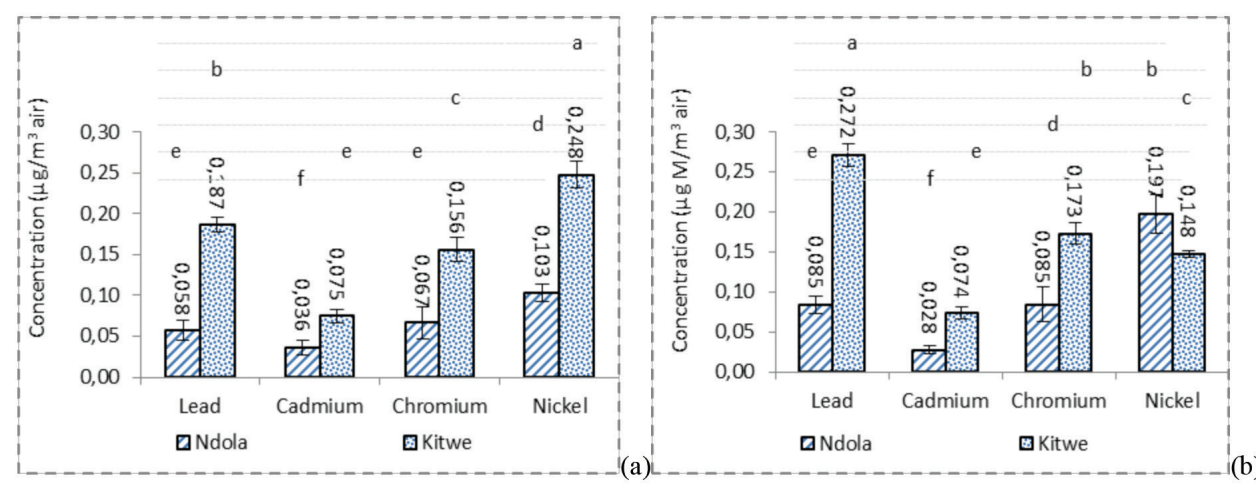

Figure 4. The concentrations of heavy metals in smoke from Pinus (a) and Eucalyptus (b) wood sawdust obtained in Ndola and Kitwe in Copperbelt provinces. Values represent means for three replicates per site. Values followed by the same letter(s) are not significantly different from one another. $\alpha=0,05$.

Both Eucalyptus and Pinus sawdust smoke from the control and treatment site contained significantly different $\mathrm{Pb}, \mathrm{Cd}, \mathrm{Cr}$ and $\mathrm{Ni}$ concentrations (ANOVA at 5\% level: $\mathrm{F}_{\text {calc. }} 126,5>\mathrm{F}_{\text {critic. }} 2,2 ; \mathrm{P}<1,8 \times 10^{-18} ; \mathrm{F}_{\text {calc. }}$ $127,8>\mathrm{F}_{\text {critic. }} 2,2 ; \mathrm{P}<2 \times 10^{-18}$ ) (Figure $4 \mathrm{a}, \mathrm{b}$ ).

The concentrations of heavy metals were below the World Health Organization guidelines' annual exposure limits of $0,2 \mu \mathrm{g} \mathrm{Cr} / \mathrm{m}^{3}, 180 \mu \mathrm{g} \mathrm{Ni} / \mathrm{m}^{3}$ and $0,2 \mu \mathrm{g} \mathrm{Cd} / \mathrm{m}^{3}$, respectively as well as $2 \mu \mathrm{g} \mathrm{Pb} / \mathrm{m}^{3}$ (WHO_Exoert Task_Force 2000). These concentrations $0,0004 \mathrm{mg} \mathrm{Cr} / \mathrm{kg} ; 0,0034 \mathrm{mg} \mathrm{Ni} / \mathrm{kg}$ and $0,00074 \mathrm{mg} \mathrm{Pb} / \mathrm{kg}$ for both wood types, were much lower than what has been observed in wood smoke from Oregon in the United States of America; 0,02-4 mg Cr/kg; 0,001-1 mg Ni/kg and 0,1-3 mg Pb $/ \mathrm{kg}$ of cordwood (Koenig 1993).

The significantly high concentrations of $\mathrm{Pb}$ in smoke from Eucalyptus $\left(0,27 \mu \mathrm{g} / \mathrm{m}^{3}\right)$ and Pinus $(0,19 \mu \mathrm{g} /$ $\mathrm{m}^{3}$ ) wood sawdust originating from Kitwe reflects the impact of industrialization and urbanization (Figure 4 $\mathrm{a}, \mathrm{b}$ ). These $\mathrm{Pb}$ concentrations in wood sawdust smoke that had been in storage for over two years in Kitwe compared very well with what had been observed for traffic related pollution in cities of developing countries; 0,3-1 $\mu \mathrm{g} / \mathrm{m}^{3}$ with extreme annual mean values of $1,5-2 \mu \mathrm{g} / \mathrm{m}^{3}$ (WHO Expert Task Force 2000, Simukunga 1999). Ambient air levels of over $10 \mu \mathrm{g} \mathrm{Pb} / \mathrm{m}^{3}$ have been reported in urban areas near smelters, whereas $\mathrm{Pb}$ level below $0,1 \mu \mathrm{g} / \mathrm{m}^{3}$ have been found in cities where leaded petrol is no longer used (WHO Exoert Task Force 2000). These results indicated that Eucalyptus and Pinus sawdust smoke is unlikely to pose a danger to users of small-scale heating and domestic energy appliances.

The cooking stoves being used in most developing countries are mostly inefficient (10 to $15 \%$ ) which leads to production of considerable amounts of smoke particles (DeKoning et al. 1985). Efficiency of sawdust stoves and other stoves being promoted in the Zambia is commonly assessed in terms of usable thermal output and the associated biomass savings. Studies on heavy metal air pollution potential of these stoves are sparse. This study showed accepted short-term heavy metal concentrations in wood smoke, the long-term concentrations of at least 24 $\mathrm{h}$ is yet to be established. This is important because most women, infants and children who spend long hours in the proximity of cooking areas in poorly ventilated houses are more likely to be exposed to high dosages of heavy metal pollutants. The consideration of both stove efficiency and smoke quality (Staton and Harding nd), is a necessity to the wellbeing of biomass users in woodfuel dependent households. The reduction in risks of respiratory symptoms by women in rural Mexico who switched to using Patsari improved stove demonstrates the potential to reduce the health burden related to smoke from incomplete biomass combustion process (Zuk et al. 2006). 


\section{CONCLUSIONS}

The study indicated that the sawdust stored for a long duration of about two years at air pollution levels similar to Kitwe urban was not suitable for mulching, composting and animal bedding as chromium; cadmium and nickel concentrations will most likely exceed the acceptable thresholds of $25 ; 1,5$ and $50 \mathrm{mg} / \mathrm{kg}$ respectively.

It was also found that wood smoke generated under experimental conditions in this study was unlikely to endanger users of small-scale heating and domestic energy systems as the level of toxic substances investigated complied with the World Health Organization guidelines on annual exposure limits of $0,2 \mu \mathrm{g} \mathrm{Cr} / \mathrm{m}^{3} ; 180 \mu \mathrm{g}$ $\mathrm{Ni} / \mathrm{m}^{3}$ and $0,2 \mu \mathrm{g} \mathrm{Cd} / \mathrm{m}^{3}$.

\section{REFERENCES}

ASTM E 872-82 2006. Standard Test Method for Volatile Matter in the Analysis of Particulate Wood Fuels. ASTM: West Conshohocken.

ASTM D 4442-92 2003. Standard Test Method for Direct Moisture Content Measurement of Wood and Wood-Base Materials. ASTM: West Conshohocken.

Abelson, P. 1994. Domestic wood burning. Journal of Sources of Dioxin Science (266): 350-352.

Aksoy, A.; Sahin, U.; Duman, F. 2000. Robinia pseudoacacia L. as a possible biomonitor of heavy metal pollution in Kayseri. Turkish Journal of Botany 24(5): 279-284.

Ambulkar, N.M.; Chutke, N.L.; Aggarival, A.L.; Garg, A.N. 1994. Multi elemental analysis of ambient air dust particulate from a cement factory by Neutron activation. Sci Total Environ 141: 93-101.

Audu, A.A.; Lawal, A.O. 2005. Variation in metal contents of plants in vegetable garden sites in Kano metropolis. Journal of Applied Science and Environmental Management 10(2): 105-109.

Baltrenaite, E.; Butkus, D.; Booth, C. 2010. Comparative of three tree-ring sampling methods for trace metal analysis. Journal of Environmental Engineering and Landscape Management 18(3): 170-178.

British Standard Institution. BSI. 2012. Specification for the requirements and test methods for processing waste wood. Publicly Available Specification. London

Butcher, S.S.; Sorenson, E.M. 1979. A study of wood stove particulate emissions. Journal of the Air Pollution Control Association 29(7): 724-728.

Cambra, K.; Martnez, T.; Urzelai, A.; Alonso, E. 1999. Risk analysis of a farm area near a lead and cadmium-contaminated industrial site. Journal of Soil Contamination 8(5): 527-540.

Chaiyo, U.; Garivait, S.; Wilairat, D. 2011. Trace element and carbon content in particulate emission from tropical deciduous forest fire Chiangmai. Journal of International Science and Technology 6(2): 234.

Daly, A.; Zannetti, P. 2007. An Introduction to Air Pollution - Definitions, Classifications, and History. In Ambient air pollution. P. Zannetti, D. Al-Ajmi and S. Al-Rashied, The Arab School for Science and Technology and The EnviroComp Institute: 1-14. 
Dekoning, H.W.; Smith, K.R.; Last, J.M. 1985. Biomass fuel combustion and health. Bulletin ofthe World Health Organization 63(1): 11-26.

Dimple, L. 2014. Adsorption of heavy metals, A review. International Journal of Environmental Research and Development 4(1): 41-48.

Duruibe, J.O.; Ogwuegbu, M. O. C.; Egwurugwu, J.N. 2007. Heavy metal pollution and human biotoxic effects. International Journal of Physical Sciences 2(5): 112-118.

Environmental Protection Agency 1984. Technical Support Document for Residential Wood Combustion. Document EPA-450/4-85-012, Nero and Associates: Oregon, Portland.

Energy Regulation Board 2008. Energy Sector Report.Energy Regulation Board: Lusaka.

Energy Regulation Board 2012. January-October Newsletter. The Energy Regulator Newsletter. Lusaka, Energy Regulation Board.

Gingrich, S.; Macfarlane, R. 2002. Air Pollution from Wood-burning Fire places and Stoves. Toronto Public Health: Toronto: 1-18.

Koenig, T.L.J. 1993. A summary of the emissions characterisation and noncancer respiratory effects of wood smoke. O. o. A. Q. P. Standards, US Environmental Protection Agency.

Kord, B.; Mataji, A.; Babaie, S. 2010. Pine (Pinus eldarica Medw.) needles as indicator for heavy metals pollution. International Journal of Environmental Science and Technology 7(1): 79-84.

Lake, D.L.; Kirk, P.W.; Lester, J.N. 1984. The fractionation characterization and speciation of heavy metals in sewage sludge and sewage sludge amended soils. Journal of Environmental Quality 13: 175-183.

Larson, T.; Koenig, J. 1993. A summary of the emissions characterization and non-cancer respiratory effects of wood smoke. EPA-453/R-93-046 US EPA.

Lawal, A.O.; Batagarawa, S.M.; Oyeyinka, O.D.; Lawal, M.O. 2011. Estimation of heavy metals in Neem tree leaves along Katsina-Dutsinma-Funtuahingway in Katsina state of Nigeria. Journal of Applied Science and Environment Management 15(2): 327-330.

Levine, J. S. 1990. Convener of Chapman Conference on Global Biomass Burning - Atmospheric, Climate and Biospheric Implications, March 19-23, Williamsburg (Virginia). NASA Langley Research Centre: Hampton.

Leteinturier, B.; Laroche, J.; Masslaisse, F. 2001. Reclamation of lead/zinc processing wastes at Kabwe, Zambia A Phytogeo-chemical approach. South African Journal of Science 97: 624-627.

Luckey, T.; Venugopal, B.; Hutchson, D. 1975. Heavy metal toxicity, safety and homology. Qual. Suf. Thieme Stuttgart, Supplement 1: 120.

Lumber Millers Of Zambia. 2013. Current status of timber industry.

Lupupa, A.S. 1997. Concentration and toxicity levels of heavy metal pollutants in soils and vegetation in Kitwe. MSc dissertation. University of Zambia: Lusaka. 
Mala, J.; Machova, P.; Cvrckova, H.; Vaner, T. 2007. Heavy metals uptake by the hybrid aspen and rowan-tree clones. Journal of Forest Science 53: 491-497.

Nwajei, G.E.; Iwegbue, C.M.A. 2007. Trace elements in sawdust particles in the vicinity of sawmill in Sapele, Nigeria. Pakistan Journal of Biological Sciences 10: 4311-4314.

Onder, S.; Dursun, S. 2006. Air borne heavy metal pollution of Cedruslibani (A. Rich.) in city center of Konya (Turkey). Atmosphere and Environment 40(6): 1122-1133.

Passwater, R.A.; Cranton, E.M. 1993. Trace Element: Hair Analysis and Nutrition, Hew Canan Ct, Keasts, p. 38.

Ragland, K.W.; Aerts, D.J. 1991. Properties of Wood for Combustion Analysis. Bioresource Technology 37: $161-168$.

Ravindra, K.; Mittal, A.K.; Van Grieken, R. 2001. Health Risk Assessment of Urban Suspended Particulate Matter with Special Reference to Polycyclic Aromatic Hydrocarbons: A Review, Review on environmental health 16: 169-189.

Simfukwe, E. 2010. Programme for basic energy conservation - Impact Assessment Evaluation for Zambia. GTZ: Lusaka.

Simukunga S. 1999. Status of Air Pollution in Zambia, University of Zambia: Lusaka. 1-9.

Seregin, I.V.; Ivanov, V.B. 2001. Physiological aspects of cadmium and lead toxic effects on higher plants. Russian Journal of Plants Physiology 48(4): 523-544.

Staton, D. M.; Harding, M.H. nd. Health and Environmental Effects of Cooking Stove Use in Developing Countries. 1-41.

United Nations Environmental Protection/Global Program Of Action. 2004. Why the Marine Environment Needs Protection from Heavy Metals,' UNEP/GPA Coordination Office.

Voutsa, D.; Grimanis, A.; Samara, C. 1996. Trace elements in vegetables grown in industrial areas in relation to soil and air particulate matter. Environmental Pollution 94: 325-335.

Ward, N.I.; Brooks, R.R.; Reeves, R.D. 1974. Effects of lead from motor vehicle exhausts on trees along a major through fare in Palmerstone North, New Zealand. Environmental Pollution 6: 149-158.

World Health Organization. 2000. Guidelines for Air Quality, Geneva.

Who Expert Task Force. 2000. Guidelines for air quality. Geneva, World Health Organisation.

Wu, C.; Zhang, L. 2010. Heavy metal concentrations and their possible sources in paddy soils of a modern agriculture zone, south-east hern China. Environmental Earth Sciences 60: 45-56.

Yilmaz, S.; Zengin, M. 2004. Monitoring environmental pollution in Erzurum by chemical analysis of Scot pine (Pinus sylvestris L) needles. Environment International 29(8): 1041-1047. 
Zambia Forestry And Forest Industries Corporation. 2008. Plantation Management Plan 2008-2013. Plantation Management Plan. Ndola.

Zambia National Association Of Sawmillers. 2014. Members.

Zuk, M.; Rojas, L.; Blanco, S.; Serrano, P.; Cruz, J.; Angeles, F.; Tzintzun,G.; Armendariz, C.; Edwards, R.D.; Johnson, M.; Riojas-Rodriguez H.; Masera O. 2006. The impact of improved woodburning stoves on fine particulate matter concentrations in rural Mexican homes. Journal of Exposure Science and Environmental Epidemiology: 17: 224-232. 